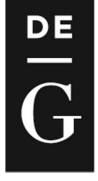

DE GRUYTER

OPEN

DOI: 10.1515/jolace-2015-0009

\title{
Learning from teachers and pupils in literature: case-based aesthetic reading in EFL teacher education
}

\author{
Harald Spann \\ University College of Education Upper Austria, Austria \\ harald.spann@ph-ooe.at
}

\begin{abstract}
Claims for the value of literature in EFL teaching and learning traditionally centre around three models: the cultural, language, and the personal growth model (Carter \& Long, 1991). In the context of EFL teacher education, the core question is: can literature also contribute to the professional development of EFL trainee teachers and, if so, how? Based on the assumption that school-related English-language literature can be used for professional casebased work this paper reports a context-specific interdisciplinary model of literature in education which synthesizes case theory (Steiner, 2004) and the theory of dialogic aesthetic reading (Delanoy, 2002), thus providing an educational setting for both literary experience and professional learning in EFL teacher education.
\end{abstract}

Keywords

English-language literature, aesthetic reading, case-based work, EFL teacher education

\section{Introduction}

It is probably not possible to agree on the goals of teaching literary texts (Showalter, 2003, p. 22). And yet, in light of growing tendencies in EFL education towards output-orientation, standardization and the "marginalization of literature" (Bredella \& Hallet, 2007, p. 1; my translation) which are visible in current debates on how to reform EFL teacher education curricula in Austria, it will be essential to reexamine the place of literature at teacher training colleges and schools of education.

With the cultural, the language, and the personal growth model, Carter \& Long (1991) have already provided three main reasons for the teaching of literature in educational contexts. Each of these models, so they argue, "embraces a particular set of learning objectives for the student of literature" (p. 2) and "represents different tendencies in methodology and in classroom practice" (p. 10). Given the fact that the primary objective in EFL teacher education is to prepare EFL trainee teachers for teaching English in the classroom, this raises an important question: what, in addition to the above mentioned models, can be the added value of teaching literature in EFL teacher education for the professional development of the students and what teaching methodology could help this potential unfold in EFL literature classes?

In order to answer this question, I carried out a dissertation project in which I developed a contextspecific professional growth model for EFL trainee teachers at the University College of Education Upper Austria (Spann, 2014). The aim of this paper is to outline this model which, as will be discussed below, symbiotically combines professional case theory (Steiner, 2004) and the theory of dialogic aesthetic reading (Delanoy, 2002).

The paper is divided into three parts: First, the two reference systems (case-based work and aesthetic reading) are explained and their methodological compatibility is delineated. Building on this theoretical foundation, the second part deals with the question of how case-based aesthetic reading can be implemented in the practice of EFL teacher education. Here, an eight-phase model is introduced and some methodological key issues are discussed. Finally, drawing largely on empirical data gained from a 
2-year action research project with 5 groups of EFL trainee teachers $(N=65)$, the paper takes a critical look at the potential of this model for EFL teacher development.

\section{Case-based work and aesthetic reading: a synthesis}

There is wide agreement among educational researchers that a reflective attitude towards one's teaching can be considered as a characteristic feature of teachers who act professionally. Case-based work, the collective term for the various methodological-didactical applications of cases for achieving higher standards in professions such as teaching, can offer a theory-practice interface which can contribute to the development of trainee teachers' reflective competence (Combe \& Kolbe, 2004; Kolbe \& Combe, 2004; Steiner, 2004; Gruber \& Rehrl, 2005; Reh, Geiling, \& Heinzel, 2010; Reh \& Schelle, 2010; Plaimauer, 2014). Apart from allowing trainee teachers to observe theory in practice, cases provide opportunities "to learn how to think like a teacher to develop the mindful habits that exemplify the skills, traits, and dispositions of professional practitioners" (Goldblatt \& Smith, 2005, p. 4). In short, case-based work itself is a reflective process which is geared to deepening the trainee teachers' understanding of the complexity of the teaching profession.

But what is a case and how can literary texts be suitable for professional case-based work with EFL trainee teachers? A close review of existing literature in educational science shows that the definition of what a case is largely depends on the professional context it is needed for. According to Merseth (1991, p. 4), terms such as "cases", "the case method", or "case-based instruction" evoke widely divergent views with regard to definition, purpose, and use of terms in education. In addition, case-based methods in didactical contexts often lack theoretical foundations.

Against this background, the case definition suggested by Steiner (2004), providing a sound theoretical frame of reference for case-based teaching and learning, seems to be of high relevance. In his case theory, based on Charles Sanders Peirce's epistemology, a case is defined as

a sequence of concrete events (...) of and with acting individuals (people or characters) in a specific situational-historical context. A case is characterized by the dimensions of process and time. A case consists of a series of events, mental states and incidents with individuals as agents. The facts of the case can either be real or imaginary. However, a sequence thus formally characterized only turns into a case when a perceiving subject reflects, talks, and writes about it and becomes aware of it. (Steiner, 2004, p. 14; emphasis in the original; my translation)

Hence, whether a person becomes aware of "a sequence of concrete events" depends on whether it has an effect on him or her. This only happens when it raises doubts, surprises, annoys, gives rise to controversy or disturbs this person's daily routine - in other words, when it causes confusion or "irritation".

According to Steiner, literary texts can also be used for case-based work. In his typology of casebased methods (Steiner, 2004, p. 173) he differentiates between two groups of cases that can be used in teacher education. The first group consists of cases which are directly related to the students themselves, i.e. cases in which they are encouraged to reflect on aspects of their own teaching practice (real cases). The second group consists of cases which the students are not personally involved in, which have been documented by someone else and which are now available for them in the form of written texts. These paper cases (or text cases) need not necessarily be based on real-life school incidents but can also be fictitious. Thus, school-related literary texts, i.e. texts which deal with school issues, classroom incidents, and various other professional aspects of teaching and education, can also be used here.

If "irritation" is a prerequisite for case-based work, we first need to choose school-related literary texts with a potential to confuse or "irritate" the readers, i.e. with something unexpected, strange or annoying in the text. Second, we also need an approach to the teaching of literature which focuses on the effects that a text has on its readers and which therefore provides ample opportunities for this 
"irritation potential" to unfold. Here, the theory of dialogic aesthetic reading (Delanoy, 2002) offers a suitable conceptual framework, fully compatible with case-based work.

What is dialogic aesthetic reading? This model for the teaching of literature in EFL contexts draws largely on Rosenblatt's transactional theory of the literary work. Here, the term aesthetic reading refers to a particular stance the reader adopts in relation to the text. "In aesthetic reading", Rosenblatt holds, "the reader's attention is centered directly on what he is living through during his relationship with that text" (1994, p. 25). Following Rosenblatt, Bredella (1996, p. 18) sums up the key aspects and features of aesthetic reading as follows:

- Aesthetic reading directs our attention to the interaction between text and reader and encourages us to explore how the text affects us. This implies that aesthetic reading includes a reflective element and is characterized by the dialectic between involvement and detachment.

- Aesthetic reading broadens the readers' horizons by encouraging them to put themselves into situations they have not yet experienced or may never experience.

- Aesthetic reading is less concerned with the conveying of information than with the creation of complex impressions within the reader.

- The anthropological significance of aesthetic reading is based on the insight that the full play of our cognitive and imaginative faculties gives us pleasure and that works of art are so organized that our efforts are rewarded. (...)

- Aesthetic reading is based on what readers bring to the text. Without their experiences, recollections, associations and speculations there would be no aesthetic experience. But the aesthetic experience also modifies what is brought to the text.

- Aesthetic reading promotes intercultural understanding because it encourages us to see the world from different perspectives and because it explores our images of foreigners and foreign cultures.

In light of the above, it becomes evident that, unlike formalist approaches to literature in education, aesthetic reading shares a number of characteristic features with case-based work, such as its focus on effect, interaction and dialogue. The latter is particularly true for Delanoy's (2002) theory of literary teaching in EFL classrooms with its strong emphasis on dialogic processes. Based on a hermeneutic concept of aesthetic reading, Delanoy makes a case for an interaction-based, experience-oriented, and task-based approach to working with literary texts. This invites learners to adopt a holistic reader stance and to "become involved in secondary worlds as if these fictional worlds were their habitat" (Delanoy 2005, 56). From this it can be inferred that EFL trainee teachers who read potentially irritating school-related literary texts aesthetically can enter a secondary world school, which may cause profession-related irritations and, consequently, turn the literary text into a literary text case.

If a literary text case can be generated, multiple reflective processes will be initiated. Since in teacher educational contexts all students who read literary texts are prospective EFL teachers with more or less practical teaching experience, domain-specific theoretical knowledge and different sets of tacit beliefs and subjective theories about teaching, a literary text case study provides an opportunity for students to share and critically reflect on various aspects of their "professional identity" (Lohmann, 2007, p. 69; my translation) in the EFL literature classroom. With their peers and their teacher educator they can analyse problematic classroom situations, develop teaching strategies from the safe distance and deepen their professional understanding of the teacher/pupil characters in the secondary world school. In addition, professionally relevant "good theories" (Stein, 2005; my translation) are introduced and applied to the text case in order to gain further insight into and new perspectives on the case. It should be noted, however, that this literary text-based professional dialogue between students and teacher educator only becomes possible if both dialogue partners are prepared not only to accept divergent views but also to critically question and change their own. 


\section{Implementing case-based aesthetic reading: an eight-phase model}

Having sketched out the theoretical foundation of case-based aesthetic reading, let us now turn to the question of how this approach can be implemented in the practice of EFL teacher education. Here I suggest the following Eight-Phase Model for Case-based Aesthetic Reading (see Figure 1) which provided the conceptual framework for the empirical part of the study, i.e. an action research project I carried out in order to develop a "practical theory" (Altrichter, Posch, \& Somekh, 1993) of case-based aesthetic reading for EFL teacher education at the University College of Education Upper Austria.

\section{Eight-Phase Model for Case-based Aesthetic Reading in EFL Teacher Education}
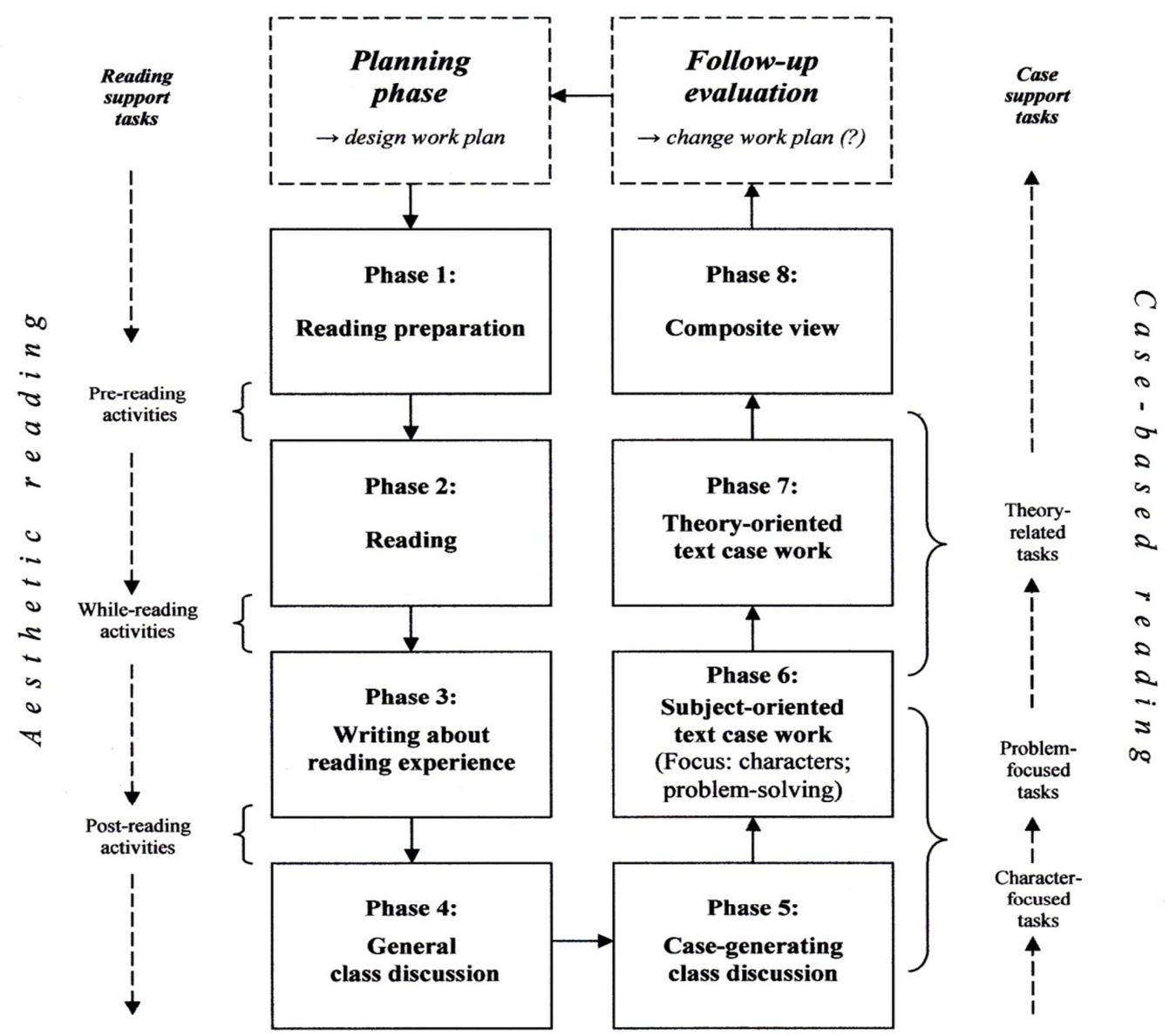

Figure 1: Eight-Phase Model for Case-based Aesthetic Reading

The model aims to depict the prototypical implementation procedure of a literary text case study in eight phases. This procedure represents the main methodological and didactical processes characteristic of case-based aesthetic reading. The eight phases do not rigidly follow a consecutive 
order but are rather fluid and frequently give rise to procedural loops. The model also includes the teacher educator's planning phase and follow-up evaluation phase, thus completing a cycle. This circularity should indicate that, from the teacher educator's perspective, a literary text case study always initiates a literary text-based action research cycle in which the teacher educator, together with the students, systematically investigates his or her work in order to improve it (Altrichter \& Posch, 2007). The graphic representation also includes two functionally different sets of tasks used in casebased aesthetic reading: reading support tasks and case support tasks.

In the following, the individual phases, their interplay and the various tasks which are used at different stages of the literary case study will be described in more detail.

\section{Planning phase}

In the planning phase the teacher educator has to develop a work plan which is based on Englishlanguage literary texts or text extracts (and/or corresponding films or film clips) which can be expected to evoke profession-related irritations in his students. Which irritations the teacher educator anticipates here largely depends on his or her "personal theory of good teaching" (Meyer, 2011, p. 136; my translation). Inseparably linked with the irritation potential anticipated by the teacher educator is the choice of a professionally relevant theory or concept which should be dealt with in the case study. Here, "good theories" are particularly suited. They provide a frame of reference which not only helps to describe and explain complex situations but also offers approaches to possible solutions for specific problems (Stein, 2005, p. 19). As my action research findings suggest, this text-theory connectability is particularly pronounced, for example, when texts including aspects of problem situations in the secondary world school are used in combination with the "ecosystemic approach to school behavioural problems" (Cooper, Smith, \& Upton, 1994). Central to this theoretical approach is the notion that "both pupils and teachers have a rational basis for behaving in the way they do but are often locked in a circular chain of increasingly negative interaction from which neither can readily escape" (Cooper, Smith, \& Upton, 1994, p. 25). To illustrate this point, here is a short extract from Alexie (2011, p. 32-35) which I, in the course of a literary case study, discussed with students from an ecosystemic perspective:

Of course, I was suspended from school after I smashed Mr. P in the face, even though it was a complete accident.

Okay, so it wasn't exactly an accident.

After all, I wanted to hit something when I threw that ancient book. But I didn't want to hit somebody, and I certainly didn't plan on breaking the nose of a mafioso math teacher. (...)

I was ashamed. I'd never really been in trouble before.

A week into my suspension, I was sitting on our front porch, thinking about stuff, contemplating, when old Mr. P walked up our driveway. He had a big bandage on his face.

"I'm sorry about your face," I said.

"I'm sorry they suspended you," he said. "I hope you know that wasn't my idea." (...)

"Well, I want you to know that hitting me with that book was probably the worst thing you've ever done. It doesn't matter what you intended to do. What happens is what you really did. And you broke an old man's nose. That's almost unforgivable."

He was going to punish me now. He couldn't beat me up with his old man fists, but he could hurt me with his old man words.

"But I do forgive you," he said. "No matter how much I don't want to. I have to forgive you. It's the only thing that keeps me from smacking you with an ugly stick. When I first started teaching here, that's what we did to the rowdy ones, you know? We beat them. That's how we were taught to teach you. We were supposed to kill the Indian to save the child.

Finally, as case-based reading is a task driven model which conceives of tasks as "pivotal forms of action in an educational process" (Legutke \& Thomas, 1991, p. 11), the teacher educator needs to design 
communicative tasks and activities which can trigger and support interactive processes between the readers and the literary texts in the aesthetic reading phase (reading support tasks) and between the readers and the (potential) literary text case in the case-based reading phase (case support tasks). The distinction between these two groups is not clear-cut. It is important to note, however, that in contrast to case-support tasks which are primarily geared towards unfolding the professional case potential, the reading support tasks also aim at facilitating the students' methodological learning on a meta-level: by trying out various pre-, while-, and post-reading activities themselves, the trainee teachers can become familiar with this classic 3-phase methodological concept of process-oriented literature teaching (Nünning \& Surkamp, 2010) and learn how to put it into practice at secondary school level.

\section{Implementation phase}

Ideally, a literary text case study can be divided into an aesthetic reading phase and a case-based reading phase, which again can be subdivided into 4 phases each.

\section{Aesthetic reading phase (phases 1-4)}

In the aesthetic reading phase the main focus is on the interaction between the students and the literary text. Here, they are invited to enter the secondary world, live through it and share their reading experience with their peers and their teacher educator.

In phase 1, reading preparation, the necessary conditions need to be established in order to make the students feel like reading and, subsequently, enable them to get into the text (Delanoy, 2002, p. 71-72). Apart from creating an atmosphere of mutual appreciation among the dialogue partners, it is therefore vital that the students' interest in the text will be aroused. In support of this, pre-reading activities, e.g. in the form of a short dialogue exchange (see below), are used:

\section{Read the following dialogue exchange:}

(A): "It's my job, sir, to mold your son's character. (...)

(B): "I'm sorry, young man, (...), but you will not mold him. I will mold him. You will merely teach him."

Work in groups (3 - 4 students) and create your own context, i.e. think of any possible explanations of

- who the characters (A) and (B) are (age, looks, clothes, etc.)

- where they are

- why they are there

- what happened/is happening/is going to happen

Report back to the class.

(I found this idea in Duff \& Maley (1990, p. 32-35) and used it slightly modified with Ethan Canin's story The Palace Thief.)

As previously stated, pre-reading activities are designed to stimulate and support aesthetic textreader interaction. At this stage of the literary case study it is therefore important not to use activities which due to their profession-related irritation potential may generate a case in their own right, thus leading the students away from rather than towards the literary text to be read.

In phase 2, reading, the students read the literary texts which the case study is based on in class. To do justice to the text itself, the while-reading activities used in this phase do not yet focus on professional issues but rather invite the students to enter an active dialogue with the text. By trying to avoid an efferent reader stance (Rosenblatt, 1994), these activities (see example below) aim to encourage the students to respond to the text holistically and, in the follow-up phase, to write about their reading experience in a journal (phase 3). 
While reading the extract underline those parts in the text that you

- like/do not like

- find irritating or confusing.

When you have finished, comment on them in your journal. Your comments can be about the reasons why you have underlined those parts, questions they raise, feelings, associations, memories, etc. Feel free to write your comments in English or German. Please provide line numbers.

In phase 3, the students' commenting on their reading experience in a journal (or reading diary) has two main objectives. On the one hand this note-taking should intensify their dialogue with the text, and the notes they record should support in-depth reflection in later stages of the case study. On the other hand the students' journals yield important action research data which, in the follow-up evaluation phase, the teacher educator can use for evaluating the literary case study and, if necessary, for reconceptualizing and redesigning the original work plan.

Phase 4, the general class discussion, concludes the aesthetic reading phase in this model. In essence, here the students are expected to fulfil their "interpretive responsibility" (Blau, 2003, p. 20) and to share their reading experience in pair, group and/or plenary discussions with their peers and with their teacher educator. As the term general already implies, the aim of these discussions is to allow for a general and open discourse between the dialogue partners (texts, students, teacher educator) who can compare and contrast how the text has affected them and who can bring up any questions the text raises, including e.g. literary, linguistic or historical-cultural questions. The role of the teacher educator is primarily that of a facilitator who remains in the background and who lets the students "act openly" (Burwitz-Melzer, 2004, p. 248; my translation) in the discussion.

\section{Case-based reading phase (phases 5-8)}

Given the fact that in the general class discussion the students' interests already tend to centre around professional aspects and that even at this stage the first contours of a literary text case usually become visible, the boundaries between phase 4 and phase 5 , the case-generating class discussion, are necessarily blurred. However, it is not before this phase that the teacher educator begins to more strongly direct the students' attention towards those contributions to the discussion which show traces of the professional case potential which s/he has anticipated in the planning phase. Thereby, students are gradually guided towards the intended case study. As the students and the teacher educator often have different case interests which need to be reconciled, this phase resembles a difficult balancing act for the dialogue partners which eventually aims to consensually generate a literary text case. Generally speaking, this can be one or more characters in secondary world school contexts who can be used for illustrating something, who represent something and/or who find themselves in school-related problem situations. Depending on the primary focus of the intended case work (characters/problem-solving), profession-oriented tasks which support the case study can already be used in this phase.

In phase 6 the students deal with the text case in a subject-oriented way (Goeze, 2010; my translation). This means that they try to gain deeper understanding of the characters and the situations they are in without explicit reference to professionally relevant theories or concepts. On the one hand they are encouraged to put themselves in the school-related characters' place and suggest individual interpretations of these characters' mindsets and their (professional) (inter)actions in the secondary world (focus: characters). In addition, if these characters find themselves in difficult classroom/school situations as teachers, the students are invited to develop alternative, and even creative action strategies for these situations and to discuss them with their peers.

In phase 7 , the theory-oriented text case work, the students' findings from phase 6, i.e. their interpretations of the characters and/or the action strategies they have developed, are discussed in light of professionally relevant theoretical knowledge. Hence, it is at this stage of the case study, when a theory-practice interface is created. This interface provides an opportunity for interdisciplinary professional learning based on literary texts. As it is usually necessary that the students are introduced 
to this theoretical knowledge first, the teacher educator may need to provide a brief input covering the key aspects of this theory and, subsequently, enabling the students to carry out theory-related tasks, which are characteristic of this phase. Here is an example of a task which, after drawing a mind-map in phase 6 and after a short theoretical input on the "types of power in the classroom" (Olsen \& Cooper, 2001) my students carried out in a case study based on extracts from E. R. Braithwaite's autobiographical novel To Sir With Love.

\section{Look at the mind-map on the board. Can you find any aspects that relate to the five different} power bases?

2. Compare Braithwaite's power bases with yours as a student teacher in your practical training. Are there any similarities/differences?

It is important to note that, from a didactical viewpoint, this shift towards a theoretical perspective on professional aspects is not entirely unproblematic. As my action research findings suggest, the balance between the students' aesthetic-literary and professional-theoretical interests is particularly difficult to keep at this stage of the literary case study, thus rendering it a very delicate phase for both students and the teacher educator.

Finally, in phase 8, composite view, students and the teacher educator critically reflect on the completed literary case study in class. Unless there is a more comprehensive end-of-term evaluation (e.g. after a series of literary case studies), this phase also includes some shorter form of written feedback by the students. The data thus obtained are analysed by the teacher educator in the follow-up evaluation phase in which, depending on the outcome of this analysis, changes of the original work plan, e.g. adaptation or reconceptualization, may turn out to be necessary.

\section{Case-based aesthetic reading in practice: an action research project}

To find out how the above model works in the context of EFL teacher education, I carried out a twoyear action research project with 5 groups $(N=65)$ of EFL trainee teachers $\left(4^{\text {th }}\right.$ semester) at the University College of Education Upper Austria. My research interests can be summed up in two questions: First, from a methodological-didactical viewpoint, what problems, phenomena and processes become apparent when implementing case-based aesthetic reading with EFL trainee teachers? Second, from a professional perspective, how would the students assess the significance of case-based aesthetic reading for their professional development as EFL teachers?

The action research project was divided into two phases. In phase 1 (summer semester 2012) I carried out 5 literary text case studies with 3 groups of students in my literature classes. Based on the analysis of the qualitative data collected in this phase, I developed new action strategies to be tested in another series of 5 case studies with 2 groups of students in phase 2 (summer semester 2013). The data collection tools I employed in both phases of this empirical qualitative study included questionnaires, interviews, students' journals, audio recordings and my own research diary (see Table 1).

\begin{tabular}{ccc}
\hline & $\begin{array}{c}\text { Phase 1 } \\
\text { (summer semester 2012) }\end{array}$ & $\begin{array}{c}\text { Phase 2 } \\
\text { (summer semester 2013) }\end{array}$ \\
\hline Student groups & $3(36$ students; 14/12/10) & 2 (29 students; 14/15) \\
Case studies (per group) & 5 & 5 \\
Data collection methods & 32 & 29 \\
Questionnaires & 9 & 5 \\
Interviews & 35 & 27 \\
Students' journals & 1 & 1 \\
Research diary (author) & - & 2 \\
Audio recordings & & \\
\hline
\end{tabular}

Table 1: Key parameters of the two phases of the action research project 
The literary case studies, which lasted between three and six hours each, were based on a wide range of narrative text extracts from English-language literature which, following McRae's distinction, can be subsumed under both "Literature with a capital ' $\mathrm{L}$ '” and "literature with a small 'l'" (McRae, 1991). They included, for example, extracts from E. Waugh's classical novel Decline and Fall, contemporary novels (e.g. C. Sittenfeld's Prep, S. Alexie's The Absolutely True Diary of a Part-time Indian, K. Gray's Malarkey) or E. R. Braithwaite's autobiographical novel To Sir, With Love. In addition, I selected excerpts from novels which are based on popular films, e.g. N. H. Kleinbaum's Dead Poets Society and D. Chiel's Mona Lisa Smile, and used them with the corresponding film scenes for comparative literary case studies.

The profession-related theoretical concepts I used for the theory-oriented text case work included the ecosystemic approach to school behavioural problems (Cooper, Smith, \& Upton, 1994), types of power in the classroom (Olsen \& Cooper, 2001), professional antinomies (Helsper, 1999) and the "teacher skills checklist 1" (Stronge, 2007).

\section{Key findings of the action research project: scope and limits}

Both from a methodological-didactical and from a profession-oriented perspective my research interest concerned two complementary implementation levels of case-based aesthetic reading. At single case level, I investigated how each of the case studies I had planned would work in practice and, by gaining deeper knowledge and insight through action research, how each case study could be further developed. At course level, my research interest primarily focused on how a series of five literary case studies conducted in an EFL literature course would be assessed by the students. As an in-depth discussion of the single case studies would be beyond the scope of this paper, I will confine myself to some key findings of the action research concerning both levels. They can be summarised as follows:

\section{Case selection and students' case preferences}

Hoping for rough guidelines for the future planning of literary case studies, I was particularly interested in which cases the students preferred and what reasons they offered for their preferences. The results, however, were very ambivalent and only pointed towards a limited number of tendencies.

First, the students often preferred cases based on teachers and pupils interacting in difficult secondary world classroom situations. Such situations might invite the students to develop and reflect on possible action strategies and interventions for this concrete situation. Or, as one student put it,

[m] any of the cases we dealt with are also part of everyday school life. It is therefore beneficial to deal with them and to talk through possible reactions with other students/teacher (my translation).

From the case study which among the students ranked first in terms of popularity (case study 2 based on Mona Lisa Smile and Dead Poets Society), some further indications can be deduced which may facilitate future case selection. The students' feedback on this case study, in which book extracts and film scenes were used, suggests that text arrangements in which the teacher protagonists show a high degree of comparability are particularly suited for case-based work. In addition, the comparative nature of a literary text case can be enhanced by viewing the corresponding film scenes, thus offering further insights into the personal and professional backgrounds of the teacher protagonists.

\section{Significance of class discussions}

Most students considered the class discussions (pairs, groups, plenum) as a highly relevant platform for sharing their reading experience and discussing their profession-related views with their dialogue partners. As the following three student quotes illustrate, this sometimes helped them gain new perspectives on and a deeper understanding of the texts and their responses to them. 
The discussions were interesting because other people's thoughts made me reconsider mine. Often our thoughts were similar, but even more often I became aware of things that I had not noticed before (my translation).

I think it's very important to listen to other people's opinions and views and to accept them. That's what happened in the plenary discussions - sometimes I had an aha-moment - I could also see it exactly like that (my translation).

I found the plenary discussions very pleasant and informative, as it was possible (in connection with theory) to delve deeply into the character's behaviour (my translation).

Apart from findings related to literature in the EFL classroom, the data also suggested a linguistic benefit. With regard to the class discussions some students positively commented on the L 2 context of this course, as here, so they argued, they had ample opportunity to practice their EFL speaking skills. As this interactive language work mainly took place in the semantic field of school, classroom and education, it can be assumed that the students were also able to improve their domain-specific language competence in these phases.

\section{In-class reading and journal writing}

In-class reading and journal writing are both constitutive elements of the 8-phase-model. It was therefore important to find out how the students would assess these two phases. While their feedback did not not point towards any major difficulties with reading the text extracts in class, the data obtained on the follow-up phase of journal writing is ambivalent. Although some students considered the commenting on their reading in a journal as an interesting phase supporting reflective processes, it was also regarded as quite a challenging task which takes some time to get used to. In addition, there are indications that some students experienced journal writing as increasingly monotonous, not least because of the repetitive character of the course which, for data collection purposes, included a series of five cases studies with almost identical while-reading activities.

\section{Professional relevance of the model from the students' perspective}

One of the primary goals of this model was to offer an EFL learning environment where trainee teachers were invited to engage interactively with school-related literary texts and to link this readertext interaction with professionally relevant theories. At this theory-practice interface the students were not only expected to engage in subject-oriented professional reflection but also to increase their domain-specific theoretical knowledge through actively working with exisiting knowledge of educational theory or other related fields of study.

The research findings suggest that this goal was not fully achieved. On the one hand the students' responses indicate that the case studies supported their professional development by initiating (selfJreflective processes relating to their personal "teacher's mind-set" (Bach, 2009, p. 304). A literary case study can therefore be conceived of as an opportunity for secondary world classroom observation which facilitates profession-related reflective learning. Or, as a student put it in an interview,

[w]ell, I found it totally interesting to meet so many different teacher personalities and to learn about different school types, simply in a kind of "trial run", just to observe in a stress-free atmosphere and to really ask myself how would I have reacted or how would I react or what would I expect here. Just thinking through it raises questions which you normally wouldn't think of because you are not confronted with it (my translation). 
On the other hand the degree of relevance the students assigned to the profession-related theoretical input was in general lower than I had expected. The following three quotes show declining degrees of the theoretical input's acceptance.

In my opinion, the theory and the theoretical part presented with the extracts were suitable and adequate. It was also interesting to see how literary texts can be scientifically underpinned (my translation).

The theoretical input was good, but for my taste not substantial enough (...) (my translation).

(...) not that interesting because we have other courses dealing with it and that's why I already feel 'overloaded' as far as theory at PH is concerned (my translation).

All this suggests that in case-based aesthetic reading it is of utmost importance to provide a theorypractice interface where the necessary balance between the students' literary interests and their professional-theoretical interests is maintained. As my action research has shown, this balance is very difficult to achieve. The theoretical input can easily be too short and thus lacking depth, or it can take too much time, keeping the students away from the text for too long.

On the positive side, it must finally be mentioned that there are indications in the data of literary text case studies supporting the students' methodological learning and reviving their interest in reading literary texts. Not least because of the "Peter Effect" in reading education does the latter seem to be of particular importance in EFL teacher education. According to Applegate \& Applegate, this effect refers to "the condition characterizing those teachers who are charged with conveying to their students an enthusiasm for reading they do not have" (2004, p. 556).

\section{Conclusion}

In sum, the findings of my 2-year action research are encouraging. Despite some obvious limitations concerning the interface between aesthetic reading and case-based reading, the 8-phase model seems to have great potential: at best, it can contribute to the professional development of EFL trainee teachers by providing an educational environment which, apart from fostering literary and foreign language learning, stimulates and supports literature-based professional reflection. However, I initially developed this model as an action researcher in the context of a specific teacher education college. Therefore, all results are preliminary and it remains to be seen whether they prove relevant to other EFL teacher educational contexts.

As the model was developed to trace the added value of teaching literature in EFL teacher education, it can only aim to be considered as an additional offer to literature in education, i.e. one which, at curriculum level, may provide a high-quality complement to already existing approaches in tertiary literature programmes.

To further develop case-based aesthetic reading in theory and practice, more research will be necessary. Among others, three desiderata seem to be particularly important. Firstly, as the quality of a literary case study largely depends on the case potential of the selected literary texts, a comprehensive English-language literature search will be required in order to increase the pool of suitable schoolrelated texts for case work. Secondly, it will also be of great importance to find new domain-specific theories in educational science or other profession-related fields which are likely to provide a wellbalanced theory-practice interface, thus opening up new interpretive dimensions to the future teachers. Thirdly, it will be necessary to systematically combine both school-related literary texts and theory in a literary text case matrix which subsequently could serve as a basis for implementing a literary text case archive in an EFL teacher education institute.

Finally, in times of increasing student mobility it would also be interesting to carry out an international literary text case project in which language students and teacher educators from different 
countries share text cases taken from their respective literatures and carry out literary text case studies in an educational context with English as a second/foreign language.

\section{Acknowledgements}

The author wishes to thank his colleagues, Christina Crawford and Thomas Wagner, for their critical comments on earlier drafts of this paper.

\section{References}

Alexie, S. (2011). The Absolutely True Diary of a Part-time Indian. 2007. London: Andersen Press.

Altrichter, H. \& Posch, P. (2007). Lehrer erforschen ihren Unterricht. Bad Heilbrunn: Verlag Julius Klinkhardt.

Altrichter, H., Posch, P., \& Somekh, B. (1993). Teachers Investigate their Work. London/New York: Routledge.

Applegate, A. J. \& Applegate, M. D. (2004). The Peter Effect: Reading habits and attitudes of preservice teachers. The Reading Teacher (57), 6, 554-563.

Bach, G. (2009). Alltagswissen und Unterrichtspraxis: der Weg zum reflective practitioner. In Bach, G. \& Timm, J. (Eds.), Englischunterricht (p. 304-320). Tübingen/Basel: A. Francke Verlag.

Blau, S. (2003). The Literature Workshop. Teaching Texts and their Readers. Portsmouth, NH: Heinemann.

Braithwaite, E. R. (1987). To Sir With Love. 1959. New York: Jove Books.

Bredella, L. (1996). The Anthropological and Pedagogical Significance of Aesthetic Reading. In Bredella, L. \& Delanoy, W. (Eds.), Challenges of Literary Texts in the Foreign Language Classroom. Giessener Beiträge zur Fremdsprachendidaktik (p. 1-29). Tübingen: Gunter Narr Verlag.

Bredella, L. \& Hallet, W. (2007). Einleitung: Literaturunterricht, Kompetenzen und Bildung. In Bredella, L. \& Hallet, W. (Eds.), Literaturunterricht, Kompetenzen und Bildung (p. 1-9). Trier: Wissenschaftlicher Verlag.

Burwitz-Melzer, E. (2004). Unterrichtsgespräche beim Einsatz von Literatur im Fremdsprachenunterricht. In Bredella, L. \& Burwitz-Melzer, E., Rezeptionsästhetische Literaturdidaktik mit Beispielen aus dem Fremdsprachenunterricht Englisch. Giessener Beiträge zur Fremdsprachendidaktik (p. 237-324). Tübingen: Gunter Narr Verlag.

Canin, E. (1994). The Palace Thief. New York: Picador USA.

Carter, R. \& Long, M. N. (1991). Teaching Literature. Harlow: Longman.

Chiel, D. (2003). Mona Lisa Smile. London: Penguin Books-ONYX.

Combe, A. \& Kolbe, F. (2004). Lehrerprofessionalität: Wissen, Können, Handeln. In Helsper, W. \& Böhme, J. (Eds.), Handbuch der Schulforschung (p. 833-851). Wiesbaden: VS Verlag für Sozialwissenschaften.

Cooper, P., Smith, C. J., \& Upton, G. (1994). Emotional \& Behavioural Difficulties. Theory to Practice. London: Routledge.

Delanoy, W. (2002). Fremdsprachlicher Literaturunterricht. Theorie und Praxis als Dialog. Giessener Beiträge zur Fremdsprachendidaktik. Tübingen: Gunter Narr Verlag.

Delanoy, W. (2005). A Dialogic Model for Literature Teaching. ABAC Journal , 25(1), 53-66.

Duff, A. \& Maley, A. (1990). Literature. Oxford: Oxford University Press.

Goeze, A. (2010). Was ist ein guter Fall? Kriterien für die Entwicklung und Auswahl von Fällen für den Einsatz in der Aus- und Weiterbildung. In Schrader, J., Hohmann, R., \& Hartz, S. (Eds.), Mediengestützte Fallarbeit. Konzepte, Erfahrungen und Befunde zur Kompetenzentwicklung von Erwachsenenbildnern (p. 125-145). Bielefeld: W. Bertelsmann Verlag.

Goldblatt, P. F. \& Smith, D. (2005). Cases for Teacher Development - Preparing for the Classroom. Thousand Oaks: Sage Publications.

Gray, K. (2003). Malarkey. London: Random House.

Gruber, H. \& Rehrl, M. (2005). Praktikum statt Theorie? Eine Analyse relevanten Wissens zum Aufbau pädagogischer Handlungskompetenz. Journal für Lehrerinnen- und Lehrerbildung, 1, 8-16. 
Helsper, W. (1999). Antinomien des Lehrerhandelns in modernisierten pädagogischen Kulturen. Paradoxe Verwendungsweisen von Autonomie und Selbstverantwortlichkeit. In Colbe, A. \& Helsper, W. (Eds.), Pädagogische Professionalität. Untersuchungen zum Typus pädagogischen Handelns (p. 521569). Frankfurt am Main: Suhrkamp.

Kleinbaum, N. H. (1989). Dead Poets Society. New York: Bantam.

Kolbe, F. \& Combe, A. (2004). Lehrerbildung. In Helsper, W. \& Böhme, J. (Eds.), Handbuch der Schulforschung (p. 853-877). Wiesbaden: VS Verlag für Sozialwissenschaften.

Legutke, M. \& Thomas, H. (1991). Process and Experience in the Language Classroom. London/New York: Longman.

Lohmann, G. (2007). Mit Schülern klarkommen. Professioneller Umgang mit Unterrichtsstörungen und Disziplinkonflikten. Berlin: Cornelsen Verlag.

McRae, J. (1991). Literature with a small 'l'. London: Macmillan.

Merseth, K. K. (1991). The Case for Cases in Teacher Education. Washington: AACTE Publications.

Meyer, H. (2011). Was ist guter Unterricht? Berlin: Cornelsen Verlag Scriptor.

Nünning, A. \& Surkamp, C. (2010). Englische Literatur unterrichten 1. Grundlagen und Methoden. Seelze: Kallmeyer/Klett.

Olsen, J. \& Cooper, P. (2001). Dealing with Disruptive Students in the Classroom. London: Kogan Page Limited.

Plaimauer, C. (2014). Vom Fall zur Erkenntnis zum Wissen - Kasuistik und fallorientierte Methoden in der Lehrer_innenbildung. In Feyerer, E., Hirschenhauser, K., \& Soukup-Altrichter, K. (Eds.), Last oder Lust? Forschung und Lehrer_innenbildung. Beiträge zur Bildungsforschung Band 1. (p. 133-146). Münster: Waxmann-Verlag.

Reh, S., Geiling, U., \& Heinzel, F. (2010). Fallarbeit in der Lehrerbildung. In Friebertshäuser, B., Langer, A., \& Prengel, A. (Eds.). Handbuch Qualitative Forschungsmethoden in der Erziehungswissenschaft (p. 911924). Weinheim/München: Juventa Verlag.

Reh, S. \& Schelle, C. (2010). Der Fall im Lehrerstudium - Kasuistik und Reflexion. In Schelle, C., Rabenstein, K., \& Reh, S. Unterricht als Interaktion - Ein Fallbuch für die Lehrerbildung (p. 13-23). Heilbronn: Verlag Julius Klinkhardt.

Rosenblatt, L. M. (1994). The Reader, the Text, the Poem. The Transactional Theory of the Literary Work. Carbondale/Edwardsville: Southern Illinois UP.

Showalter, E. (2012). Teaching Literature. Oxford: Blackwell Publishing.

Sittenfeld, Curtis. (2005). Prep. New York: Random House.

Spann, H. (2014). Englischsprachige Literatur als Fall. Ein kasuistisch-rezeptionsästhetisches Literaturdidaktikmodell für die Ausbildung angehender EnglischlehrerInnen an der Pädagogischen Hochschule Oberösterreich. Doctoral thesis, University of Klagenfurt, Austria.

Stein, G. (2005). Sozialpsychologie des Schulalltags. Das Miteinander in der Schule. Stuttgart: Verlag W. Kohlhammer.

Steiner, E. (2004). Erkenntnisentwicklung durch Arbeiten am Fall: Ein Beitrag zur Theorie fallbezogenen Lehrens und Lernens in Professionsausbildungen mit besonderer Berücksichtigung des Semiotischen Pragmatismus von Charles Sanders Peirce. Doctoral thesis, University of Zurich, Switzerland.

Stronge, J. H. (2007). Qualities of Effective Teachers. Alexandria: ASCD.

Waugh, E. (1993). Decline and Fall. 1928. London: Random House.

\section{Contact address}

Harald Spann, Mag. Dr. Dr.

University College of Education Upper Austria

Kaplanhofstraße 40

A-4020 Linz

Austria

harald.spann@ph-ooe.at 